\title{
The Strawberry Line's Breeding Birds and their Biophilic Benefits (Vale of Winscombe Section)
}

\author{
LINCOLN GARLAND
}

(Contact email: lincoln.garland@biodiversitybydesign.co.uk)

\begin{abstract}
The Strawberry Line is a linear Local Nature Reserve extending along a dismantled railway corridor in North Somerset, England. The Reserve is cherished as a recreational resource by local communities and I am very fortunate to live beside it. During the COVID-19 lockdown of spring 2020, I decided to make use of my permissible daily exercise to record the distribution of breeding birds along my particular 'patch' of the Strawberry Line - the Vale of Winscombe section in the Mendip Hills. In describing the Reserve's birdlife, I hope that I can provide an added layer of interest for locals and visitors, which might help in these difficult times deliver an enhanced dose of 'Nature's Fix' and perhaps also shine a light towards a greater appreciation and connection with the natural world.
\end{abstract}

\section{Keywords}

Breeding birds; bird diversity; birdsong; biophilic; mental wellbeing; Nature's Fix; Strawberry Line; Vale of Winscombe; Mendip Hills

\section{Introduction}

The Strawberry Line, or Cheddar Valley Railway Line, is a footpath/cycleway extending for 10 miles along a dismantled railway corridor between Yatton and Cheddar in North Somerset, England. It is deeply cherished by neighbouring communities and I am very fortunate to have lived alongside it for the last six years. Over this time, I have become increasingly familiar with its natural seasonal rhythms, including those of its birdlife, which are the subject of this article.

During the COVID-19 lockdown, I decided to make use of my permissible daily exercise to record the distribution of the breeding birds along my particular 'patch' of the Strawberry Line - the Vale of Winscombe section. This stretch of the Strawberry Line breaches the picturesque Mendip Hills between Sandford Station and Shute Shelve Tunnel, passing through the village of Winscombe at the halfway point (Figure 1). I was partly inspired into action by what I perceived to be a high abundance of birdlife along the Strawberry Line in contrast with neighbouring, relatively intensively managed, farmland but also compared with some local Ancient woodlands, where birdsong often seems conspicuous by its absence.

As a consequence of the lockdown and associated reduction in noise pollution, multiple media stories have described how the pace of life slowed for many people, who in turn became increasingly cognizant of their natural surroundings, and in particular of birdsong and the psychologically healing (biophilic) effect that nature's soundscape can have. This is not simply an intuitive understanding; scientific evidence is also revealing a positive relationship between birdsong and mental wellbeing (Bakolis et al., 2018). In telling the story of the Strawberry Line's birdlife I hope that I can provide an added layer of interest for locals and visitors, which might also help in these difficult times deliver an enhanced dose of 'Vitamin N' or 'Nature's Fix', to borrow the biophilic terminology of Richard Louv (2017) and Florence Williams (2017) respectively.

Field survey methods and statistical analysis procedures are set out in the accompanying appendix.

\section{Setting}

The Mendip Hills, in which the Vale of Winscombe is set, are designated as an Area of Outstanding Natural Beauty. In Shirley Toulson's book - The Mendip Hills: A Threatened Landscape (1984) - she describes the Vale of Winscombe as "one of the most pleasant and sheltered valleys of the Mendip" (see also Garland, 2016). The Vale consists of a mosaic of mixed farmland, newly planted orchards, and small scattered woodlands, and is encircled by 

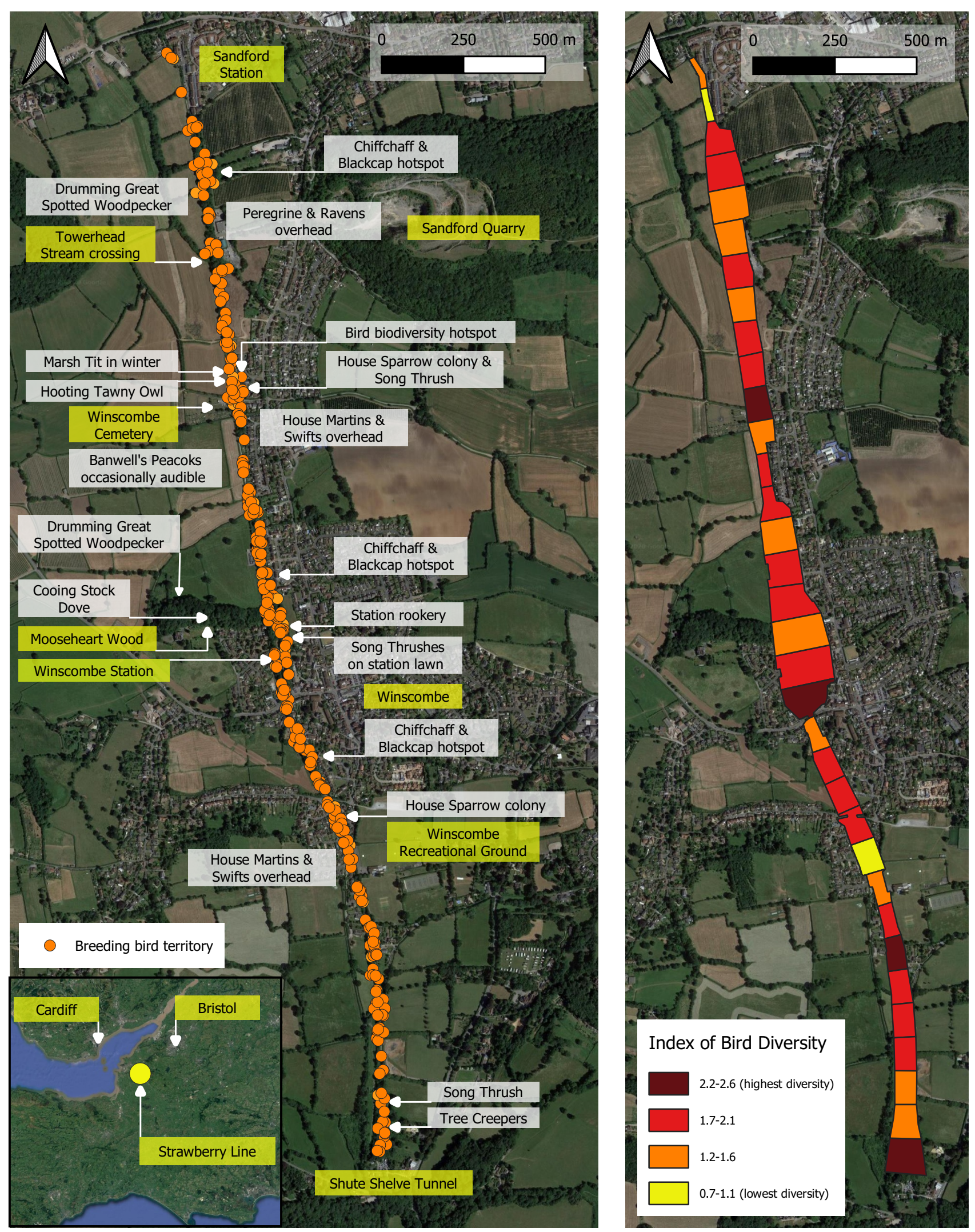

Figure 1 (left) Distribution of breeding bird territories along the Strawberry Line

Figure 2 (right) Variation in breeding bird diversity along the Strawberry Line as measured by the ShannonWeiner Diversity Index (N.B. the width of the Strawberry Line has been exaggerated [increased c. three-fold] for clarity 
some of the Mendips' most distinctive hilltops and ridgelines; Wavering Down and Crook Peak being most prominent (Plate 1). Various nature conservation designations are assigned to the extensive areas of Ancient woodland and flower-rich grasslands that cloak these hills. The ridgelines bounding the Vale of Winscombe to the north and south, extending perpendicular to each end of the Strawberry Line, engender a sense of enclosure and geographical integrity not found along any other stretch of the Line.

The Vale of Winscombe section consists of a series of wooded and shrub-lined cuttings and raised embankments, and is designated as a Local Nature Reserve and Site of Nature Conservation Interest (Plate 2). It traverses the breadth of the Vale for a distance of approximately $3.4 \mathrm{~km}$ and covers 8.5 ha (c. 12 football pitches), varying in width between 3 $\mathrm{m}$ and $57 \mathrm{~m}$ (mean width $25 \mathrm{~m}$ ).

\section{Breeding Birds}

This story begins in spring, my favourite season when nature erupts with sound and colour, and the dawn chorus, in particular, brings for me a new spirit of optimism. During six survey visits to the Strawberry Line in spring 2020, I recorded 22 breeding species occupying 311 territories (Figure 1; Table 1), although this is likely to underestimate the true number, especially of less territorial species (Newson et al., 2005). Registrations were only included for birds singing specifically along the Strawberry Line corridor or within approximately $10-15 \mathrm{~m}$ of it, as the goal was to estimate the number and variety of breeding birds focused on the Strawberry Line itself, rather than recording every bird within 'earshot', many of which were probably nesting elsewhere.

The Strawberry Line's most abundant breeding bird was the Wren (64 pairs). Although diminutive in stature, the Wren makes up for it with its remarkably powerful song that could be heard on average every $50 \mathrm{~m}$ or so along the Line. In some locations, their oral jousting was less than $10 \mathrm{~m}$ apart, with males blasting out their song in defiance of each other (and to attract females) from either side of the footpath.

The next most abundant species were Robin (37 pairs), Wood Pigeon (27 pairs), Blackbird (22 pairs),
Goldfinch (20 pairs), and Dunnock (20 pairs). The Strawberry Line's four most common breeding birds are in the UK's top six, which also includes the House Sparrow and Chaffinch (Woodward et al., 2020). The House Sparrow (13 pairs), which has been declining nationally for many years and is now Red listed (highest conservation priority), was the eleventh most abundant breeding species along the Strawberry Line. Listen out for their incessant chirruping from two colonies; one in the vicinity of Winscombe Cemetery and the other near to Winscombe Recreational Ground. In both locations the roof tiles of many adjoining houses are semicylindrical, providing convenient cavities under which the Sparrows can nest.

Each spring I welcome back like old friends, the migrant warblers - the Chiffchaffs (20 pairs) and Blackcaps (19 pairs). My special fondness for these birds comes partly out of admiration for their surviving the travails of migration, undertaking journeys from the north and west of Africa respectively, after which they re-establish territories in their familiar spots along the Strawberry Line. Except, both species have an average lifespan of only two years, and so I am often greeting new arrivals, or perhaps yearlings returning to their natal territory to take the place of their parents. Migrant birds have a hardwired disposition to return to their natal territories, referred to as natal philopatry, which has many potential benefits, including knowledge of where to find food, a nesting site, and presence of conspecifics (and thus opportunities to find a mate) (Rappole, 2013). In spring my regular walks and runs into the village are enlivened every $100 \mathrm{~m}$ or so by a singing male of both species; the two typically being ensconced close to one another among mature trees with dense shrubby understorey. The Chiffchaff is named onomatopoeically for its uncomplicated 'chiff chaff' song, while the song of the Blackcap often begins with a series of scratchy notes before it seemingly clears its throat and bursts into a delightful flute-like warble, giving it its nickname as the Northern Nightingale. These bedfellows even seemed to courteously take turns to sing. Presumably, it is wasted effort to sing if your territorial announcement is going to be drownedout' by your neighbour. 


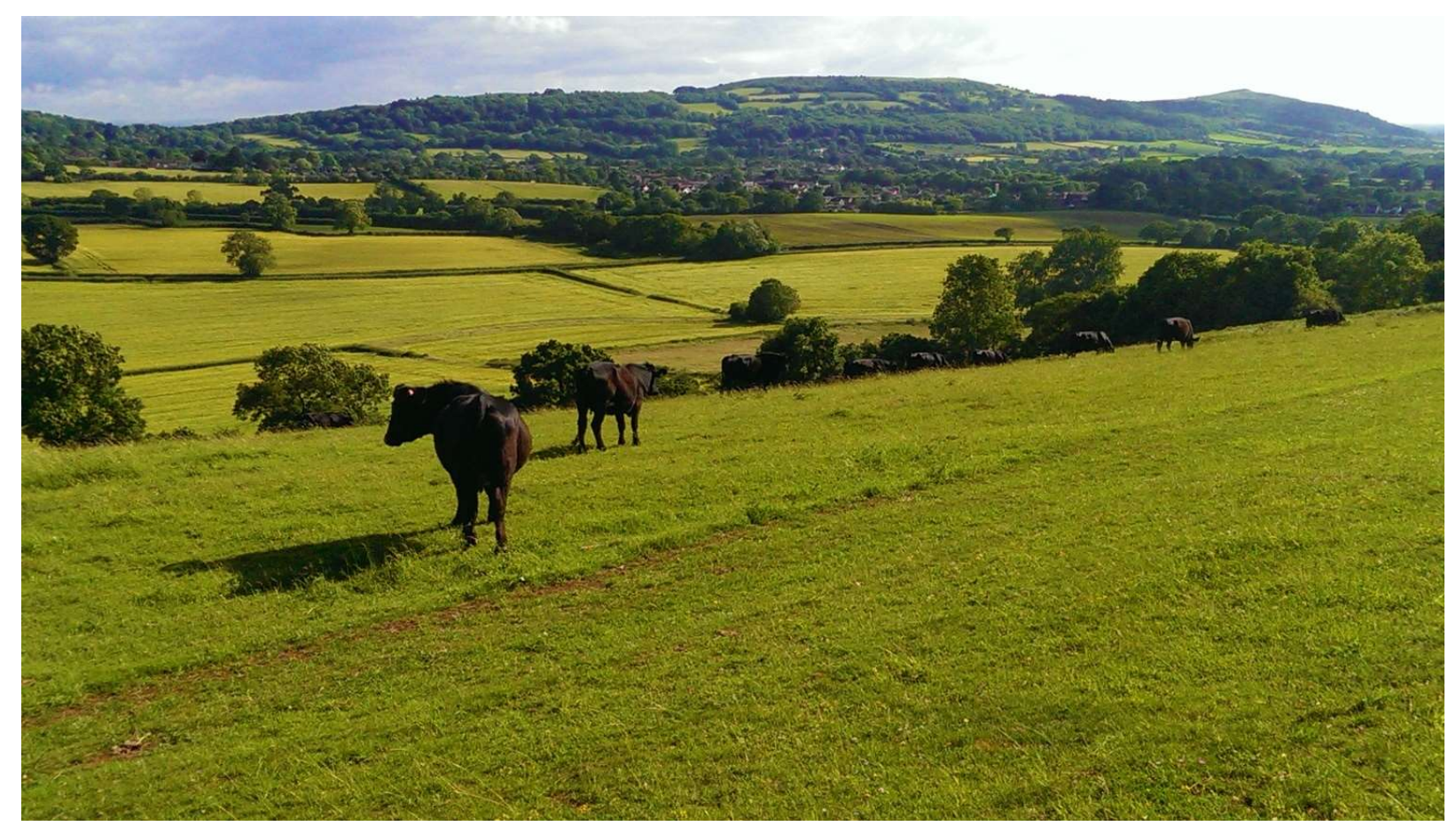

Plate 1. Vale of Winscombe in the Mendip Hills; the Strawberry Line crosses the Vale in the mid-distance; Wavering Down and Crook Peak can be seen in the background

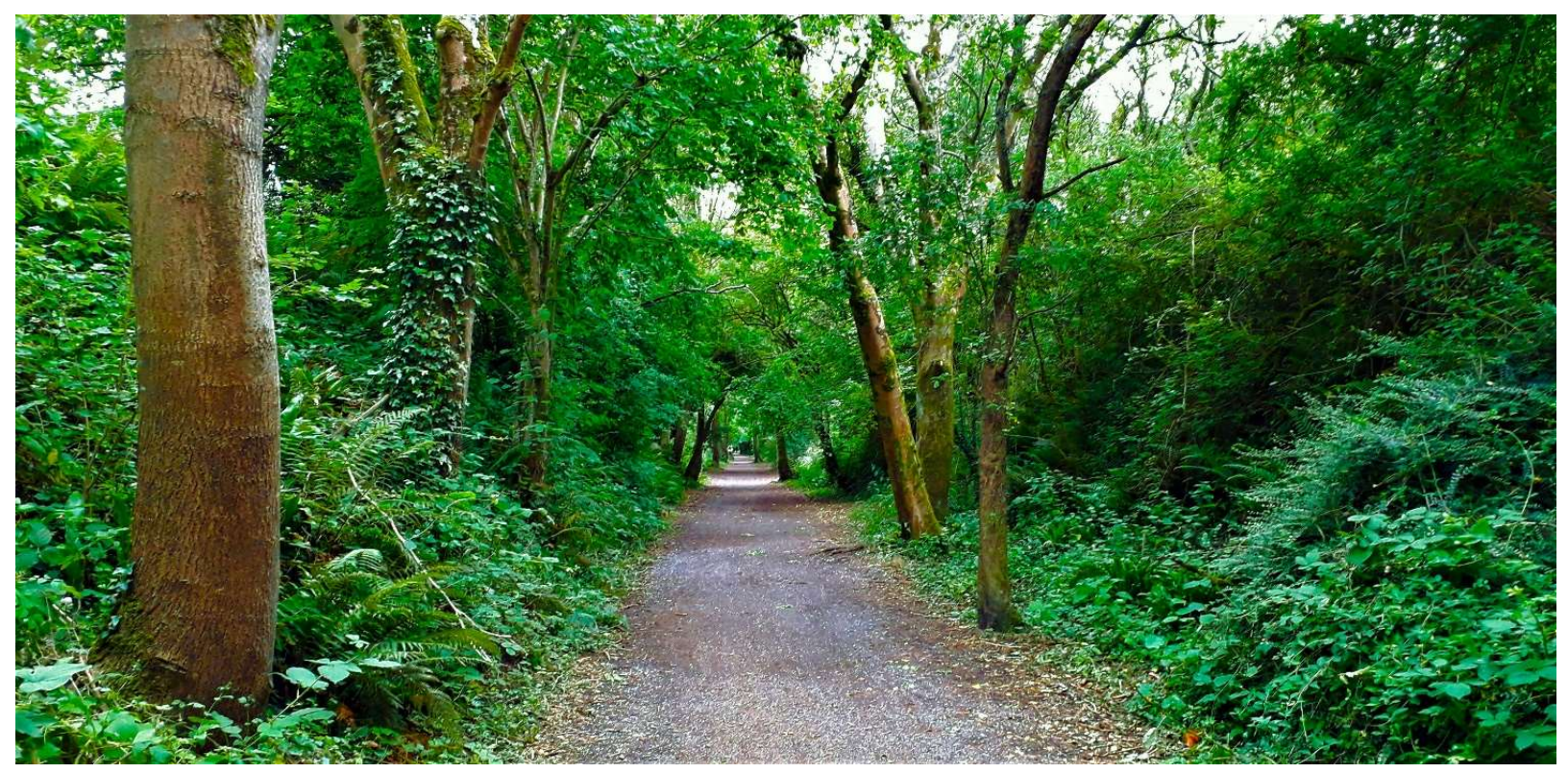

Plate 2. Wooded cutting along the Strawberry Line near Sandford Station 
Table 1. Breeding birds recorded along the Strawberry Line

\begin{tabular}{|c|c|c|c|c|}
\hline Rank & & s name & Conservation status* & No. territories \\
\hline 1 & Wren & Troglodytes troglodytes & & 64 \\
\hline 2 & Robin & Erithacus rubecula & & 37 \\
\hline 3 & Wood Pigeon & Columba palumbus & & 27 \\
\hline 4 & Blackbird & Turdus merula & & 22 \\
\hline 5 & Goldfinch & Carduelis carduelis & & 20 \\
\hline 6 & Dunnock & Prunella modularis & SPI; AL & 20 \\
\hline 7 & Blue Tit & Cyanistes caeruleus & & 19 \\
\hline 8 & Chiffchaff & Phylloscopus collybita & & 19 \\
\hline 9 & Blackcap & Sylvia atricapilla & & 18 \\
\hline 10 & Rook & Corvus frugilegus & & 15 \\
\hline 11 & Great Tit & Parus major & & 13 \\
\hline 12 & House Sparrow & Passer domesticus & SPI; RL & 13 \\
\hline 13 & Chaffinch & Fringilla coelebs & & 6 \\
\hline 14 & Goldcrest & Regulus regulus & & 4 \\
\hline 15 & Magpie & Pica pica & & 3 \\
\hline 16 & Song Thrush & Turdus philomelos & SPI; RL & 3 \\
\hline 17 & Starling & Sturnus Vulgaris & RL & 2 \\
\hline 18 & Collared Dove & Streptopelia decaocto & & 2 \\
\hline 19 & Bulfinch & Pyrrhula pyrrhula & SPI; AL & 1 \\
\hline 20 & Coal Tit & Periparus ater & & 1 \\
\hline 21 & Greenfinch & Carduelis chloris & & 1 \\
\hline 22 & House Martin & Delichon urbicum & $\mathrm{AL}$ & 1 \\
\hline
\end{tabular}

*SPI - Section 41 (Natural Environment and Rural Communities Act 2006) Species Principal Importance; RL - Red listed; AL - Amber listed N.B. While Long-tailed Tits could be frequently seen and heard along the Strawberry Line and probably breed, two registrations were never recorded from a single location and thus no breeding territory was confirmed

In late April and early May listen out for another migrant warbler, the Willow Warbler. Although very similar to the Chiffchaff in appearance (olivebrown above and buff below), its song is strikingly different, having a sweet liquid-like decrescendo form, "as though golden treacle had been poured over the landscape", in the words of Mark Avery (2020). Sadly, Willow Warblers have significantly declined in southern England and those to be heard along the Strawberry Line are no longer breeding but passing through on migration, occasionally stopping to sing on their journey as a reminder of what we have lost (reasonable numbers of Willow Warbler do though still breed on surrounding hills).

Garden Warblers were also once fairly common along the Vale of Winscombe section of the Strawberry Line according to Kidder \& Brading (1999) but now only occur in relatively small scrubby patches on nearby hills. While I am endeavoring here to celebrate the apparent richness of the Strawberry Line's birdlife, local losses of Willow and Garden Warblers reveal a danger of shifting baseline syndrome, or "pre-baseline amnesia ... a continuous lowering of standards and acceptance of degraded natural ecosystems", to quote Isabella Tree (2018) of Knepp Estate fame. What now seems fairly common may also become increasingly rare if the current national downward trend in birdlife continues.

Like the House Sparrow and Willow Warbler, the Song Thrush is another species that has declined significantly at a national level and is Red listed, although at least three pairs could still be readily heard singing along the Strawberry Line. While their song divides opinion, I find it amongst the most spellbinding. They possess an extensive repertoire of more than 100 phrases, each seemingly selected at random, and thus with each verse is the gift of surprise. As the Song Thrush is one of the first and last to sing before sunrise and after sunset respectively, isolation from most other natural sounds accentuates the song's mesmerizing effect. Listen out for them when passing by both Winscombe Cemetery and Winscombe Station; they also frequently forage on the lawn areas of the latter site. 
As the majority of birds rely on insects, at least for part of their diets, insect abundance would seem to be a major factor in explaining the richness and abundance of birds attracted to the Strawberry Line compared with neighbouring areas. The catastrophic decline in insect abundance across the wider countryside is one of the primary reasons explaining the freefall in Britain's birdlife (Macdonald, 2018; Goulson, 2019). The wide diversity and varied structure of trees and shrubs along the Strawberry Line, including insect-critical species such as Oak, Hawthorn, Blackthorn, and Bramble (Kennedy \& Southwood, 1984), provides its birdlife with a rich feeding resource. Journey a short distance from the Strawberry Line into the adjacent countryside, and very few birds can be heard from the numerous neatly trimmed hedgerows. Certainly, Chiffchaff and Blackcap, which are so abundant along the Strawberry Line, are absent from these manicured hedgerows. When I first moved to the Vale of Winscombe the song of Yellowhammer, popularized by Enid Blyton's mnemonic 'a-little-bit-of-breadand-no-cheese', could still be heard from hedgerows in two locations, one either side of Winscombe village. This spring I heard none, which is in keeping with the national decline of this species, related to intensive farmland management. Similarly, the small population of Lesser Whitethroats inhabiting the hedgerows in the mid-valley area appears precarious.

Six members of the corvid or crow family can be regularly encountered along the Strawberry Line Carrion Crow, Jackdaw, Jay, Magpie (3 pairs), Raven, and Rook (at least 15 pairs). Regretfully, these birds are among nature's most maligned species, considered unwelcome from farmland to bird feeders, and are frequently portrayed in literature as harbingers of doom. I however embrace the presence of these highly intelligent animals. I am entertained by the antics of the Magpies and Jackdaws. The magnificent croaks and honks of Ravens from nearby Sandford Quarry, evoke memories of my previous life living in Snowdonia and its misty moorlands. Best of all, I am enthralled by the boisterous rookery in the treetops of Winscombe Station. In early spring, when the trees are still bare, look for the multiple bundles of sticks in the upper canopy at the northern end of the Station. Nearly exclusively, it is the males that can be seen constantly moving back and forth between the rookery and nearby pasture, returning each time to the colony with mouths jammed-full of worms and other invertebrates to feed to the voracious chicks and females.

\section{Breeding Bird Diversity}

I estimated the 'diversity' of breeding bird species along the Strawberry Line for each $100 \mathrm{~m}$ section (34 sections in total) by calculating a statistic known as the 'Shannon-Weaver Index' (Figure 2). This is a measure of species richness combined with evenness, which means that it also takes into account how evenly distributed the numbers of each species are. I then used another statistical technique, multiple regression analysis, to test whether variation in breeding bird diversity along the Strawberry Line might be explained by variations in adjoining land-use type, as well as the area covered by the Strawberry Line per $100 \mathrm{~m}$ section (recall that the Strawberry Line varies markedly in width along its course).

In terms of adjoining land use, breeding bird diversity was significantly positively correlated with the length of adjoining village greenspace $(\mathrm{p}=0.021$; $\mathrm{t}=2.294$ ), which I defined as including residential gardens, parks, greens, a cemetery, an allotment, and a popular Local Nature Reserve called Slader's Leigh. There was also a significant positive correlation with Strawberry Line area $(p=0.038 ; t=$ 2.253). In other words, a greater diversity of breeding birds occurred on average along wider (and thus larger) sections of the Strawberry Line and those sections adjacent to village greenspaces.

It was unsurprising that the wider sections of the Strawberry Line supported a greater diversity of breeding birds, as larger habitats are likely to support a greater variety of ecological niches. It might though seem counterintuitive that sections adjoining an urban landscape had greater diversity compared with those adjacent to farmland. However, various studies have shown that urban habitats, particularly villages and suburbs with large mature gardens and parks, can support important populations of common and widely distributed bird species, some of which have experienced rapid declines (Fuller et al., 2009). Furthermore, increasingly rare species such as House Sparrow and Song Thrush are disproportionately represented in these urban environments.

In addition to birds benefiting from the rich mosaic of habitat types found in the greenspaces of villages and suburbia, populations of feeder-adapted bird species are particularly benefitting from the growing 
variety of foodstuffs that we are provisioning for them (Plumber et al., 2019). In the bird box that I installed on the boundary between my garden and the Strawberry Line, fat balls appeared to be one of the most important constituents in the diet being fed to the resident Blue Tit nestlings. It isn't just the birds that are benefitting, an increasing body of scientific research is identifying the hedonic effects that exposure to natural stimuli seems to engender, including those specifically derived from feeding garden birds (Cox \& Gaston, 2016).

In contrast to these relatively biodiverse urban green spaces, in intensively farmed rural landscapes, many trees and hedgerows have been removed, and herbicides and pesticides have greatly reduced the abundance of weed seeds and insect prey respectively. According to The State of the UK's Birds 2012 report, the UK, shockingly, has lost 44 million breeding birds since 1966 , mostly as a result of intensive agricultural activities (Eaton et al., 2012).

\section{Other Notable Birds within Proximity of the Strawberry Line}

While not breeding along the Strawberry Line itself, the sights and sounds of a wide variety of other bird species provide additional interest for visitors. Although I am only aware of one House Martin pair nesting on housing directly adjacent to the Strawberry Line, they can be seen in good numbers above the Strawberry Line throughout spring and summer. Scimitar-shaped Swifts are equally prevalent, their screaming calls usually giving advanced warning of their arrival overhead before their aerobatic manoeuvres are glimpsed (the Swift is the world's fastest bird in level flight).

Based on my observations from numerous ramblings up and down the valley, these sociable migrants appear to disproportionately hunt for their aerial insect prey above the Strawberry Line. This is not perhaps too surprising, as insect abundance is likely to be much greater above the Strawberry Line's rich covering of trees and shrubs, in contrast with adjoining intensively managed farmland. As with the House Sparrow, the House Martins and Swifts were particularly prevalent over the Strawberry Line near to Winscombe's Cemetery and its Recreation Ground. Much lower numbers of Swallows seem to feed over the Strawberry Line, even though they can still be fairly commonly encountered across the wider valley.

Seeing or hearing a bird of prey creates a sense of drama like no other species. Three of these apex predators can be encountered fairly regularly along the Strawberry Line - Buzzard, Peregrine Falcon, and Sparrowhawk - all of which have recovered in numbers in recent decades, as the twin threat of human persecution and organochlorine pesticide poisoning has abated. The Buzzard can be readily distinguished from all other birds of prey likely to be seen, by its large size and the unmistakable 'mewing' call it makes as it lazily soars over the valley. Peregrine Falcon, the planet's fastest animal, has successfully recolonised the Western Mendips, breeding along the coast at Brean Down, as well as in quarries that mimic its traditional cliff-side haunts (N.B. all six regular Peregrine breeding sites in North Somerset successfully reared young in 2020 [T . Riddle, 2020, pers. comm.]). Even though Peregrines regularly breed near to the Sandford end of the Strawberry Line in what is a relatively serene pastoral landscape, their screeching wail-like vocalizations are for me, a true 'call of the wild' that never ceases to surprise and excite. Look out for the Sparrowhawk's 'flap-flap-glide' flight pattern it adopts when soaring, or if you are lucky, you might get a split-second glimpse of one flashing by at a low level along the outer edge of the Strawberry Line, hoping to snatch Blue Tit or House Sparrow from an adjoining garden bird feeder. Do not begrudge the Sparrowhawk its meal. Their presence along the Strawberry Line is the clearest indication of a healthy food chain. In the words of Simon Barnes, "to cherish birds of prey is to cherish everything", (RSPB, undated).

Great Spotted Woodpeckers are a common sight along the Strawberry Line, as well as a welcome visitor to neighbouring garden bird feeders. In spring listen for their territorial drumming near the Towerhead Stream crossing and from the Mooseheart Woodland, which connects with the Strawberry Line at Winscombe Station. The distinctive laughing call, or 'yaffle', of the Green Woodpecker, can be heard from most locations along the Strawberry Line. The Stock Dove, which is an attractive but elusive woodland pigeon (AmberListed), can also often be heard in the Mooseheart Woodland and can be readily identified by its distinctive two-syllable cooing. 
Finally, two exotic large ground-living birds belonging to the Phasianidae family also form a distinctive component of the Strawberry Line's spring and summer soundscape. Both are exquisitely beautiful and flamboyant species - the Common Pheasant and the Peacock. Pheasants, however, are barely accepted as a bird by most bird watchers on account of their non-nativeness and ubiquity (20 million are released annually). Yet their crowing call has become an inseparable component of most of the English countryside. When atmospheric conditions are just right, the repeated penetrating screams from the Peacocks that reside at Banwell Castle $(1.5 \mathrm{~km}$ west of the Strawberry Line) can also be heard. These birds do on occasion make quite significant forays outside of the castle grounds.

\section{Autumn and Winter Birds}

Autumn and Winter along the Strawberry Line are also not without interest in terms of birdlife, with the highlight for me being sightings of Marsh Tit. As is now sadly the case with many woodland specialists, the Marsh Tit has become increasingly scarce in the UK and is now Red listed. While I cannot remember when I last encountered one in local woods, a small population might persist, as evidenced by their not infrequent visits to the Strawberry Line in winter, which they use partly as a staging-post before venturing on to bird feeders in adjoining gardens. Note that the Marsh Tit is sedentary species that retains large year-round territories (Hinsley et al., 2007) and so given their regularity of occurrence in winter, they are unlikely to be simply passing through. If you think you have a Coal Tit on your feeder, look more closely; if it has similar coloration but there is no white patch at the back of the neck, it might be a Marsh Tit!

Redwings and Fieldfares are colourful thrush species that arrive in autumn/winter from Scandinavia, Iceland, and Russia. Flocks can rapidly strip the Strawberry Line's remaining Hawthorn berries and other fruits before moving into the adjoining pasture in search of earthworms. Another frequent earthworm consumer, the Tawny Owl (which also preys on mice and voles), can be heard hooting from late autumn and through the winter months, frequently selecting mature trees along the Strawberry Line in the vicinity of the Cemetery from which to call. Our most familiar owl however is now Amber-listed due to fears that it may be undergoing a long-term population decline.
Finally, watch out at dusk for a reasonably large, fast, low-flying flock of Starlings, always following the Strawberry Line from north to south. These birds appear to be using the Strawberry Line as a navigational aid while en route to the Somerset Levels, where they perhaps join-up with the huge Starling 'murmurations' of the Avalon marshes. The Vale of Winscombe is only approximately $16 \mathrm{~km}$ to the north of these congregations and so is within the potential daily dispersal range of a Starling. By following the Strawberry Line, which breaches the Mendip Hills via two low-lying passes (Towerhead and Shute Shelve), Starlings can access the Somerset Levels without having to expend energy flying over higher ground. Starlings are Red-listed due to severe declines in their UK breeding populations.

\section{Conclusions}

Seasoned ornithologists and bird watchers might look at the Strawberry Line's assemblage of birds as set out here and be somewhat underwhelmed. The species aren't perhaps those that many of them would travel a long distance to see, particularly when there are alternative sites of international ornithological value nearby on the Somerset Levels and Severn Estuary. But to focus on rarity alone would be to miss the point. The goal of this article is to celebrate a Local Nature Reserve that is beloved by local people as much as these other sites are by those with a more esoteric interest in wildlife.

By highlighting the good variety and abundance of relatively common birdlife (and a few less common species) that can be readily encountered over a short distance while walking the dog or strolling to the village shop, I might perhaps shine a light towards a greater appreciation and connection with the natural world. Without contact with 'local' nature, wider interest and concern for the natural world might never emerge. If this is too lofty an ambition, it would be enough to know that some people might simply have their spirits lifted, as I do, by welcoming the return each spring of the Chiffchaffs and Blackcaps, as they sing their hearts out from their usual spots along the Strawberry Line, or have the hairs on the back of their necks raised by a screech overhead from one of Sandford's Peregrines.

\section{Acknowledgements}

Thank you to Dr Stuart Newson (British Trust for Ornithology), Trevor Riddle (Yatton \& Congresbury Wildlife Action Group), Judith Tranter (Mendip 
Society), and Dr Mike Wells (Biodiversity by Design) for their kind and constructive comments.

\section{References}

Avery, M. (2020). Bird song (19) - Willow Warbler. Retrieved from: https://markavery.info/2020/04/10/bird-song-18willow-warbler/

Bakolis, I., Hammoud, R., Smythe, M., Gibbons, J., Davidson, N., Tognin, S. \& Mechelli, A. (2018). Urban mind: using smartphone technologies to investigate the impact of nature on mental well being in real time. Bioscience, 68, 134-145.

Cox, D. T. C., \& Gaston, K. J. (2016). Urban bird feeding: Connecting people with nature. PLOS ONE, 11(7).

Eaton, M.A., Cuthbert, R., Dunn, E., Grice, P.V., Hall, C., Hayhow, D.B., Hearn R.D., Holt, C.A., Knipe, A., Marchant, J.H., Mavor, R., Moran, N.J., Mukhida, F., Musgrove, A.J., Noble, D.G., Oppel, S., Risely K., Stroud, D.A., Toms, M. \& Wotton, S. (2012). The State of the UK's Birds 2012. RSPB, BTO, WWT, CCW, NE, NIEA, SNH and JNCC, Sandy.

Fuller, R.A., Tratalos, J. \& Gaston, K.J. (2009). How many birds are there in a city of half a million people? Diversity and Distributions, 15, 328-337.

Garland, L. (2016). The Vale of Winscombe: an unsung natural treasure. Mendip Times, 12, 48-49.

Goulson, D. (2019). Insect Declines and Why they Matter. South West Wildlife Trusts.

Hinsley, S.A. Carpenter, J.E., Broughton, R.K., Bellamy, P.E., Rothery, P., Amar, A., Hewson, C.M., \& Gosler, A.G. (2007). Habitat selection by Marsh Tits Poecile palustris in the UK. Ibis, 149, 224-233.

Kennedy, C. E. J. \& Southwood, T. R. E. (1984). The number of species of insects associated with British Trees: a re-analysis. Journal of Animal Ecology, 53, 455-478.

Kidder, D. \& Brading, A. (1999). Cheddar Valley Railway Walk: History and Walks Along the Former Cheddar Valley Railway Line. Ex Libris Press, Bradford on Avon.

Louv, R. (2017). Vitamin N: The Essential Guide to a Nature-Rich Life. Algonquin Books, Chapel Hill.
Macdonald, B. (2018). Rebirding: Rewilding Britain and its Birds. Pelagic Publishing, Exeter.

Newson, S.E., Woodburn, R.J.W, Noble, D.G., Baillie S.R. \& Gregory, R.D. (2005). Evaluating the Breeding Bird Survey for producing national population size and density estimates. Bird Study, 52, $42-54$.

Plummer, K.E., Risely, K., Toms, M.P. \& Siriwardena, G.M. (2019). The composition of British bird communities is associated with longterm garden bird feeding. Nature Communications, 10, 2088 (2019).

Rappole, J. (2013). The Avian Migrant: The Biology of Bird Migration. Columbia University Press, New York.

RSPB (undated). Birds of Prey in the UK: On a Wing and a Prayer. RSPB, Sandy.

Toulson, S. (1983). The Mendip Hills: A Threatened Landscape. Victor Gollancz, London.

Tree, I. (2018). Wilding: The Return of Nature to a British Farm. Pan Macmillan, London.

Williams, F. (2017). The Nature Fix: Why Nature Makes Us Happier, Healthier, and More Creative. W.W. Norton \& Company, New York.

Woodward, I., Aebischer, N., Burnell, D., Eaton, M., Frost, T., Hall, C., Stroud, D.A. \& Noble, D. (2020). Population estimates of birds in Great Britain and the United Kingdom. British Birds, 113, 69-104.

\section{Appendix: Methods}

Field Survey

In spring 2020 I undertook a systematic survey to map the distribution of breeding birds along the Strawberry Line's Vale of Winscombe section. The survey entailed six steady-paced walks, keeping to the Strawberry Line's footpath. Surveys were carried out on the 12, 16, and 22 April; 2 and 16 May; and 2 June. Each commenced at c. 05.45 am and finished at c. $08.15 \mathrm{am}$. On each occasion, conditions were dry, still, and bright (minimum and maximum temperatures $6^{\circ} \mathrm{C}$ and $15^{\circ} \mathrm{C}$ respectively). A breeding / territorial registration was only recorded when a bird was heard specifically in song, i.e. no registration was noted when a bird was simply observed or heard making a contact or distress call. In keeping with standard protocols, two registrations 
in relative proximity were required for a given species from separate visits to identify a likely breeding territory. Registrations were only included for birds singing within c. 10-15 m of the Strawberry Line corridor, as the goal was to estimate the number and variety of breeding birds specifically focused on the Strawberry Line itself, rather than recording every bird within 'earshot', many of which were probably nesting elsewhere.

Each survey commenced and finished in the same location and hence each part of the Strawberry Line (given its linear form) was covered twice during each survey visit. To prevent double-counting, registrations were only recorded on the return leg of each survey if it was clear that the bird in question had not been recorded on the outward leg. The direction of travel was alternated on each survey occasion to ensure each particular point was surveyed at different times.

All observations outside of the breeding season were from incidental observations made from the countless walks and runs I have taken along the Strawberry Line over the last six years.

\section{Statistical Analysis of Breeding Bird Diversity}

Species richness refers to the number of species found in an area. Species diversity, however, is a measure of species richness combined with evenness, which means that it also takes into account how evenly distributed the numbers of each species are. Species diversity was calculated for each $100 \mathrm{~m}$ section of the Strawberry Line (34 sections in total) using the Shannon-Weaver Index.

Multiple regression analysis was then used to provide a model of explanatory variables (using the JASP statistics program), which best explained differences in the breeding bird diversity along the Strawberry Line. Non-significant variables were omitted from the model one by one using the backward stepwise simplification procedure.

Five habitat variables were investigated to attempt to explain variations in breeding bird diversity. For each $100 \mathrm{~m}$ section of the Strawberry Line, the following information was recorded:

- Area covered by the Strawberry Line (note that the Strawberry Line varies in width between $3 \mathrm{~m}$ and $57 \mathrm{~m}$; all area calculations were made using QGIS).
- Length of wooded habitat directly bordering the Strawberry Line (woodland and hedgerows).

- Length of farmland directly bordering the Strawberry Line (arable, pasture and young orchard)

- Length of village greenspaces directly bordering the Strawberry Line (residential gardens, parkland and greens, a cemetery, an allotment, and a well-used Local Nature Reserve [Slader's Leigh]).

- Length of non-greenspace village directly bordering the Strawberry Line (roads, car parks, business premises, and an electrical sub-station). 